\title{
Atribut Produk Tabungan Bank Syariah Dan Pengaruhnya Pada Minat Nasabah Menabung
}

\author{
Ismaulina', Agus Ana Tasya ${ }^{2}, N^{1}$ urul Mailiza3 \\ 1,2Institut Agama Islam Negeri Lhokseumawe, 3UIN Sumatera Utara \\ E-mail: ismaulina@gmail.com ${ }^{1}$, tasya.a17@yahoo.com², nurulmailiza123@gmail.com³ \\ 1,2 Jl. Medan-Banda Aceh Km. 275 No.1 Alue Awe, Muara Dua, Kota Lhokseumawe
}

\begin{abstract}
Abstrak
Minat nasabah menabung sangat ditentukan oleh atribut produk perbankan yang tersedia.Tujuan penelitian ini untuk mengetahui bagaimana atribut produk tabungan perbankan syariah Bank Aceh Syariah KCP Sampoiniet mempengaruhi minat nasabah menabung. Metode yang digunakan dengan pendekatan kuantitatif dan objek penelitiannya adalah atribut produk tabungan dan minat nasabah menabung. Sampel terdiri dari 43 orang nasabah yang di ambil secara random.Data diperoleh melalui penyebaran kuesioner (angket) serta dokumentasi.Teknis analisis data melalui uji validiitas, reliabilitas, dan normalitas. Hasil penelitian menunjukkan bahwa atribut produk tabungan Bank Aceh Syariah KCP Sampoiniet telah dilakukan dengan baik terlihat dari uji statistiknya yang signifikan. Hal ini di tunjukan dengan besarnya nilai $t_{\text {hitung }}$ dengan $t_{\text {tabel }}(2.639>1.68288)$.
\end{abstract}

Kata Kunci: Atribut Tabungan, Minat Nasabah, Perbankan Syariah

\begin{abstract}
Customers' interest in saving is largely determined by the attributes of available banking products. The purpose of this research is to find out how the attributes of Islamic banking savings products at Bank Aceh Syariah KCP Sampoiniet affect customers' interest in saving. The method used is a quantitative approach and the object of research is the attributes of savings products and customer interest in saving. The sample consisted of 43 customers who were taken randomly. Data obtained through distributing questionnaires (questionnaires) and documentation. The technique of analyzing the data was through the validity, reliability and normality tests. The results showed that the attributes of the Bank Aceh Syariah KCP Sampoiniet savings product have been performed well as seen from the significant statistical test. This is indicated by the value of tcount with t-table (2.639>1.68288).
\end{abstract}

Keywords: Attributes of Savings, Customers' Interest, Syariah Banking

\section{Pendahuluan}

Penilaian konsumen terhadap perusahaan salah satunya terletak pada kualitas produknya.Produk dapat dikatakan sebagai kumpulan atribut yang berwujud ataupun tidak ber wujud, yang terangkum dalam serangkaian sebuah produk mencakup warna produk, harga, kemasan produk, dan pelayanan yang diterima oleh konsumen/nasabah, sebagai suatu hal yang dapat memuaskan kebutuhannya.Menurut 


\section{Atribut Produk Tabungan Bank Syariah Dan Pengaruhnya \\ Pada Minat Nasabah Menabung}

Ismaulina dan Agus Ana Tasya

Dorami (1992) Jika nasabah merasa puas dari atribut produk yang ditawarkan maka pembelian sebuah produk akan terjadi.Dari atribut produk konsumen dapat mengetahui manfaat dari penggunaan produk dan ini bisa membantu konsumen untuk memenuhi kebutuhan dan keinginannya.

Nasabah mengetahui kualitas produk dengan melihat dan menilai produk tabungan berdasarkan karakteristik, ciri dan atribut dari produk tersebut, (Suwarman, 2004).Oleh karenanya atribut produk haruslah mempunyai keistimewaan, keunggulan dan manfaat yang dicari oleh konsumen.Ferinadewi (2005) mengemukakanAtribut produk mengandung informasi penting tentang produk tersebut sehingga dapat dijadikan sebagai alat pengukuran minat nasabah menggunakan atau membeli produk tabungan perbankan.

Saat ini nasabah memilih sebuah produk tabungan perbanakan banyak faktor yang mempengaruhi nya dan beragam pertimbangan yang digunakan nasabah serta pilihan atribut tabungan yang ditawarkan perbankan juga menentukan, seperti: Tabungan firdaus, tabu-ngan sahara, tabunganku syariah, deposito mudharabah, giro wadiah dan masih banyak 1 a $g$ i produk tabungan lain nya.

Ditengah persaingan antar bank inilah, penawaran produk perbankan yang bervariatif sesuai dengan keinginan nasabah menjadi faktor utama dalam memengaruhi tingkat pertumbuhan simpanan nasabah diantaranya merek, fasilitas, ATM, fitur, desain, kua- litas, jaminan, harga dan atribut produk lainya. Apabila perusahaan dapat menyediakanatribut produk tabungan sesuai kebutuhan dan keinginan nasabah/konsumen, maka akan mendorong konsumen untuk menabung kembali.

Kualitas perbankan dinilai dari kualitas atribut produk tabungannya dan sekaligusmenjadi penilaian secara menyeluruh atas keunggulan sebuah perusahaan.Kualitas atribut produk berpengaruh besar pada penggunaan jasa menabung.Salah satu contoh Bank Aceh Syariah KCP Sampoiniet yang memberikan pelayanan jasa alternatif bagi masyarakat Aceh khususnya melalui cara yang lebih sesuai dengan ketentuan ajaran Islam.

Arah penelitian ini, dirumuskan menjadi bagaimana atribut produk tabungan Bank Aceh Syariah KCP Sampoiniet mempengaruhi minat nasabah dalam menabung?dan apakah atribut produk tabungan Bank Aceh Syariah KCP Sampoiniet berpengaruh secara signifikan terhadap minat nasabah dalam menabung? dengan tujuan untuk mengetahui atribut produk tabungan Bank Aceh Syariah KCP Sampoiniet mempengaruhi minat nasabah dalam menabung serta untuk mengetahui pengaruh 
atribut produk tabungan Bank Aceh Syariah KCP Sampoiniet secara signifikan terhadap minat nasabah menabung.

\section{Tinjauan Teoritik}

Dalam memenuhi kebutuhan nasabah perusahaan menawarkan produk dengan berbagai macam manfaat yang diperoleh dari produk tersebut.Karenanya produkproduk yang dihasilkan perusahaan harus memiliki ciri-ciri dan keunikan tertentu yang membedakannya dari produk perusahaan lainnya. Ciri-ciri produk tersebut tercermin dari atribut yang melekat pada sebuah produk. Untuk at-ribut produk tabungan yang berbentuk barang berwujud maupun tidak berwujud, perusahaan memiliki atribut atau karakteristik tertentu.Atribut sebagai pembeda produk dapat berupa fisik, warna, label, harga, kemasan pelayanan dan sebagai nya, serta atribut produk juga menjadi daya tarik bagi nasabah. Untuk melakukan pembelian produk, atribut produk menjadi salah satu faktor yang dipertimbangan konsumen dan ini mempunyai pengaruh terhadap minat beli konsumen, maka dari itu perusahaan harus menjadikan atribut produk sebagai faktor penting dan merupakan daya tahan bagi konsumen (Tjiptono, 2008).

Kerangka fikir mengenai pengaruh atribut produk tabungan terhadap minat nasabah menabung di Bank Aceh Syariah Kantor Cabang Pembantu Sampoiniet yaitu:

\begin{tabular}{|c|c|}
\hline Atribut Produk Tabungan(X) & Minat Menabung(Y) \\
\hline Indikator: & Indikator: \\
\hline 1. Tidak mengandung unsur riba & 1. Fasilitas yang memadai \\
\hline 2. Hasil inves-tasi dibagi menurut & 2. Produk tabungan \\
\hline sistem bagi hasil & 3. Lokasi kantor capem/kas yang \\
\hline $\begin{array}{l}\text { 3. Meng-hindari unsur gambling/judi } \\
\text { (maisir) }\end{array}$ & $\begin{array}{l}\text { memudahkan akses dalam } \\
\text { menabung }\end{array}$ \\
\hline 4. Melakukkan investasi yang halal & 4. Pertimbangan sebelum menjadi \\
\hline 5. Melakukan aktivitas sesuai dengan & nasabah \\
\hline syari’ah & 5. Keputusan menjadi nasabah \\
\hline
\end{tabular}

\section{Metode Penelitian}

Penelitian ini menggunakan analisis deskriptif kuantitatif dengan studi kasus.Data oservasi di kumpul kan dan di olah agar pihak lain dapat dengan mudah memperoleh gambaran mengenai objek dari penelitian tersebut (Arikunto, 2012).Lalu menjawab pertanyaan serta menganalisis pengaruh antar variabel, yakni atribut 


\section{Atribut Produk Tabungan Bank Syariah Dan Pengaruhnya \\ Pada Minat Nasabah Menabung}

Ismaulina dan Agus Ana Tasya

produk tabungan terhadap variabel minat nasabah menabung di Bank Aceh Syariah KCP Sampoiniet. Data-data yang telah diperoleh akan di interprestasikan dalam bentuk pemaparan dan analisa sehingga dapat memberikan kesimpulan pada penelitian ini. Penulis membagikan angket atau kuesioner kepada responden/nasabah sebagai sumber data primer. Sedang kan data sekunder diperoleh melalui studi dokumentasi dengan mempelajari ber-bagai macam tulisan, bisa melalui buku, jurnal, televisi, koran, dan majalah serta situs internet untuk mendukung penelitian.

Populasi merupakan obyek dan subyek yang mempunyai karakteristik tertentu yang ditetapkan sipeneliti untuk dipelajari, dalam penelitian ini adalah nasabah Bank Aceh Syariah KCP Sampoiniet, yang berjumlah 1016 orang, kemudian barulah ditarik kesimpulannya (Sugiono, 2011). Sampel diambil dengan menggunakan teknik Simple Random Sampling, dari anggota populasi tanpa memperhatikan strata/tingkatan dalam anggota populasi tersebut, dan menetapkan nilai presisi sebesar 15\%. Jumlah sampel ditentukan dengan rumus yang dikemukakan oleh Ridwan (2007) sebagai berikut:

$n=\frac{N}{N(d)^{2}+1}$

Keterangan:

$\mathrm{n}=$ Jumlah sampel yang dicari

$\mathrm{N}=$ Jumlah populasi

$\mathrm{d}^{2}=$ Nilai presisi yang di tetapkan (0.15)

Jumlah sampel keseluruhan yang ditentukan berdasarkan rumus diatas adalah:

$$
\begin{aligned}
& n=\frac{N}{N(d)^{2}+1}=\frac{1016}{1016(0,15)^{2}+1} n=\frac{1016}{22,86+1} \\
& \quad=42.58 \\
& \mathrm{n}=43 \text { (dibulatkan) } \\
& \text { Jadi, sampelnya sebesar } 43 \text { orang/responden. }
\end{aligned}
$$

Metode pengumpulan data dilakukan dengan cara penyebaran kuesioner/Angket yang dibuat dalam bentuk daftar pertanyaan untuk memperoleh jawaban dari para responden (Koentjaraningrat, 1994). Kuesioner ini di distribusikan kepada nasabah yang sedang melakukan transaksi di Bank Aceh Syariah KCP Sampoiniet.

Sedangkan data Dokumentasi diperoleh dari pengumpulan beberapa informasi tentang data dan fakta yang berhubungan dengan masalah dan tujuan penelitian, baik dari sumber dokumen yang di publikasikan atau tidak di publikasikan, buku-buku, jurnal ilmiah, koran, majalah, website dan lain-lain. Metode ini dilakukan dengan me- 
ngumpulkan data tentang gambaran umum Bank Aceh Syariah (BAS) seperti sejarah singkat, visi dan misi, struktur dan produk Bank Aceh Syariah KCP Sampoiniet dan sebagainya.

Data penelitian dianalisis dengan Analisis deskriptif kuantitatif, yaitu menganalisis data dengan perhitungan angka-angka melalui regresi linier sederhana. Hal ini digunakan untuk mengetahui hubungan dan pengaruh antara variabel atribut produk tabung-an pada BAS (Bank Aceh Syariah) Kantor Capem Sampoiniet sebagai variabel $\mathrm{X}$ /independen terhadap minat nasabah menabung sebagai variabel $\mathrm{Y}$ atau dependen (Alqifari, 2003).

Uji Validitas. Tinggi rendahnya validitas instrument menunjukkan sejauh mana data yang ter- kumpul tidak menyimpang dari gambaran tentang variabel yang dimaksud. Uji validitas meng-gunakan rumus koefisien korelasi person yaitu:

$$
r=\frac{n\left(\sum X Y\right)-\left(\sum X \sum Y\right)}{\sqrt{\left[n \sum X^{2}-\left(\sum X\right)^{2}\right]\left[n \sum X^{2}-\left(\sum X\right)^{2}\right]}}
$$

Keterangan:

$\mathrm{r} \quad=$ Kore-lasi produk moment

$\sum \mathrm{X}=$ Jumlah skor item

$\sum \mathrm{Y}=$ Jumlah total skor jawaban

$\sum \mathrm{X}^{2}=$ Jumlah kuadrat skor jawaban suatu item

$\sum \mathrm{Y}^{2}=$ Jumlahkuadrat total skor jawaban

$\sum \mathrm{XY}=$ Jumlah per-kalian skor jawaban suatu item dengan totalskor

Uji Reliabilitas. Uji reliabel dimaksudkan sebagaipengukuran hasil dari suatu pengukuran yang telah dilakukan dapat di percaya. Pengujian reliabelitas instrumen dilakukan secara Internal Con- sisten-cy, yaitu mencoba instrumen sekali saja (Dwi, 2008). Uji ini menggunakan rumus Alpha Cron-bach sebagai berikut:

$$
r_{11}=\left(\frac{k}{k-1}\right)\left(1-\frac{\sum \sigma_{b^{2}}}{\sigma^{2} t}\right)
$$

Keterangan:

$r_{11}=$ Instrumen Reliabilitas

$\mathrm{k}=$ Banyak nya butir pertanyaan/peryataan

$\sum \sigma_{\mathrm{b}}^{2}=$ Jumlah perhitungan varian butir

$\sigma^{2}{ }_{t}=$ Total Varians

Uji Normalitas. Pengujian normali-tas di tandai dengan model regresi dengan variabel dependen dan independen, yang berdistribusi normal atau tidak. Model regresi di kata kanbaik bila mendapatkan distribusi data normal. Untuk mendeteksinya menggunakan analisis grafikdengan melihat normalitas residual serta 


\section{Atribut Produk Tabungan Bank Syariah Dan Pengaruhnya \\ Pada Minat Nasabah Menabung}

Ismaulina dan Agus Ana Tasya

melihat grafik histogram yang membandingkan antara data observasi dengan distribusi yang mendekati distri-busi normal.

Metode lain yang digunakan dalam analisis grafik adalah dengan melihat Normal Pro- bability Plot yang membandingkan distribusi kumulatif dari distribusi normal. Apabila distribusi data residual normal, maka garis yang digambarkanpada data sesungguhnya akan mengikuti garis diagonalnya.

Analisis data digunakan rumus regresi liniear sederhana sebagai berikut:

$\mathbf{Y}=\boldsymbol{\alpha}+\boldsymbol{\beta} \mathbf{X}$

Keterangan:

$\mathrm{Y}=$ varibel terikat (dependen) yaitu minat nasabah menabung

$\mathrm{X}=$ variablel bebas (independen) adalah atribut produk tabungan

$\alpha=$ nilai konstanta harga $Y$ jika $X=0$

$\beta=$ arah garis atau ko-efisiensi regresi, yang menun-jukkan angka peningkatan ataupun penurunan variable dependen yang di dasarkan pada variabel independen.

Untuk memastikan variabel $\mathrm{X}$ berpengaruh ter-hadap $\mathrm{Y}$, maka penulis menggunakan uji t-test.

Uji Statistik $\boldsymbol{t}$ (Uji $\boldsymbol{t}$ ).Uji t meng gambarkan seberapa jauh pe-ngaruh variabel independen dalam menerang- kan variasi variabel inde-penden, oleh karena itu uji t ini digunakan untuk menguji hipo- tesis (Buwi, 2008).

Langkah-langkah pengujiannya adalah sebagai berikut:

a. Merumuskan Hi p o t e s i s

Ho $=$ atribut tabungan tidak berpengaruh terhadap minat nasabah menabung di Bank Aceh Syariah (BAS) KCP Sampoiniet.

$\mathrm{Ha}=$ atribut produk tabungan berpengaruh terhadap minat nasabah menabung di

Bank Aceh Syariah KCP Sampoiniet.

b.Menentukan Tingkat Signifikan

Jikanilai signifikansi t>0,05 maka Ho diterima dan Ha ditolak

Sebaliknya bila signifikan $\mathrm{t}<0,05$ maka Hnull ditolak dan Halternatif diterima

c. Membandingkan $t_{\text {hitung }}$ dengan $t_{\text {tabel }}$

Apabila $t_{\text {hitung }}<t_{\text {tabel }}$ maka Hnull diterima dan Halternatif ditolak

Dan bila $t_{\text {hitung }}>t_{\text {tabel }}$ maka Ho ditolak dan Ha diterima. 
Koefisien Determinasi ( $R$ Square). $R$ square digunakan untuk mengetahui berapa besar pengaruh variabel terikat pada model regresi dalam menjelaskan variabel bebas. Nilai $R$ square yang baik yang semakin mendekati angka satu dansama dengan satu, yang ber-arti semakin besar menunjukkan pe- ngaruh variabel bebas (X) terhadap variabel terikat.

\section{Hasil Dan Pembahasan}

Uji validitas di laksana kan dengan uji signifikan yang membandingkan $\mathbf{r}_{\text {hitungdan }} \mathbf{r}_{\text {tabel }}$ untuk deg-ree of freedom $(\mathrm{df})=(\mathrm{n}-\mathrm{k})$ dimana $\mathrm{n}$ adalah banyaknya sampel dan $\mathrm{k}$ adalah jumlah varia-ble. Dalam penelitian ini, diketahui $\mathrm{n}$ adalah 43 sampel dan k berjumlah 2 variabel sehingga besarnya $\mathrm{df}$ adalah 43-2 = 41 dengan alpha $0.05(\alpha=5 \%)$.

Dari hasil pengujian validitas kuesioner yang terdapat dalam angket, maka berikut hasil uji validitas.

\section{Tabel 1}

Hasil Uji Validitas Instrumen

\begin{tabular}{|l|l|l|l|l|}
\hline Variabel & $\begin{array}{l}\text { Item } \\
\text { Pertanyaan }\end{array}$ & $\mathbf{R}_{\text {hitung }}$ & $\mathbf{R}_{\text {tabel }}$ & Keterangan \\
\hline \multirow{4}{*}{ Atribut Produk } & 2 & 0,641 & 0,301 & Valied \\
Tabungan (X) & 3 & 0,732 & 0,301 & Valid \\
& 4 & 0,665 & 0,301 & Valid \\
Minat Nasabah & 5 & 0,761 & 0,301 & Valid \\
Menabung (Y) & 2 & 0,577 & 0,301 & Valid \\
\hline & 3 & 0,762 & 0,301 & Valid \\
& 4 & 0,807 & 0,301 & Valid \\
\hline & 5 & 0,715 & 0,301 & Valid \\
& 0,406 & 0,301 & Valid \\
\hline
\end{tabular}

Sumber: output S P S S

Tabel 1 di atas menunjukkan bahwa nilai pada kolom corrected item total correlation untuk masing-masing item memiliki $r_{\text {hitung }}$ lebih besar di banding $r_{\text {tabel }}$ untuk $(\mathrm{df})=(43-2)=$ 41 dan al-pha 0.05 di peroleh $r_{\text {tabel }}$ sebesar 0.301, dan kesimpulannya bahwa semua indikator dari kedua variable tersebut adalah valid.

Uji Reliabilitas. Uji angket dilakukan untuk membuktikan kualitas dari angket, dengan uji reliabilitas. Satu item per-tanyaan dapat diterima/(reliable) untuk dilanjutkan dalam pengolahan statistik bila memiliki Cronbach Alpha lebih dari o.6o. Hasil pengujian reliabilitas instrument masing-masing item menggunakan alat statistik SPSS for windows versi 22 dapat diketahui sebagaimana dalam tabel berikut. 
Tabel 2

Hasil Uji Reliabilitas Instrumen

\begin{tabular}{|l|l|l|l|}
\hline Variabel & Reliabilty Coefficients & Alpha & Keterangan \\
\hline $\begin{array}{l}\text { Atribut Produk } \\
\text { Tabungan (X) }\end{array}$ & 5 Item & 0,706 & Reliabel \\
\hline Minat Menabung (Y) & 5 Item & 0,703 & Reliabel \\
\hline
\end{tabular}

Sumber: output SPSS

Tabel 2 diketahui bahwa setiap variabel mempunyaiCronbach Alpha lebih dari 0.60 sehingga kesimpulannya variabel $\mathrm{X}$ dan $\mathrm{Y}$ bersifatreliabel. Adapun hasil dari tiap-tiap variabel sebagaimana tergambar dalam tabel 4.3 di bawah ini

Tabel 3

Atribut Produk Tabungan (X)

\begin{tabular}{|l|l|l|}
\hline $\begin{array}{l}\text { Cron-bach's } \\
\text { Alpha }\end{array}$ & $\begin{array}{l}\text { Cronbach's Alpha Based on } \\
\text { Standardized Items }\end{array}$ & N of Items \\
\hline, 706 &, 703 & 5 \\
\hline \multicolumn{2}{|c|}{ Sumber: output SPSS }
\end{tabular}

Dari tabel di atas Cronbach's Alpha dari 5 item pertanyaan yaitu sebesar 0.706 melewati batas minimal sebesar 0.60 dengan demikian instrumen penelitian ini memiliki reabilitas yang baik (reliabel).

\begin{tabular}{|c|c|c|}
\hline \multicolumn{3}{|c|}{$\begin{array}{c}\text { Tabel } 4 \\
\text { Minat Menabung (Y) }\end{array}$} \\
\hline $\begin{array}{l}\text { Cronbach's } \\
\text { Alpha }\end{array}$ & $\begin{array}{l}\text { Cronbach's Alpha Based } \\
\text { on Standardized Items }\end{array}$ & $\mathrm{N}$ of Items \\
\hline, 703 & ,701 & 5 \\
\hline
\end{tabular}

Sumber: output SPSS

Dari tabel di atas Cronbach's Alpha dari 5 item pertanyaan yaitu sebesar 0.703 melewati batas minimal sebesar 0.60 dengan demikian instrumen penelitian ini memiliki reabilitas yang baik (reliabel).

\section{Uji Normalitas}

Hasil analisis data dengan SPSS diperoleh grafik sebagai berikut: 


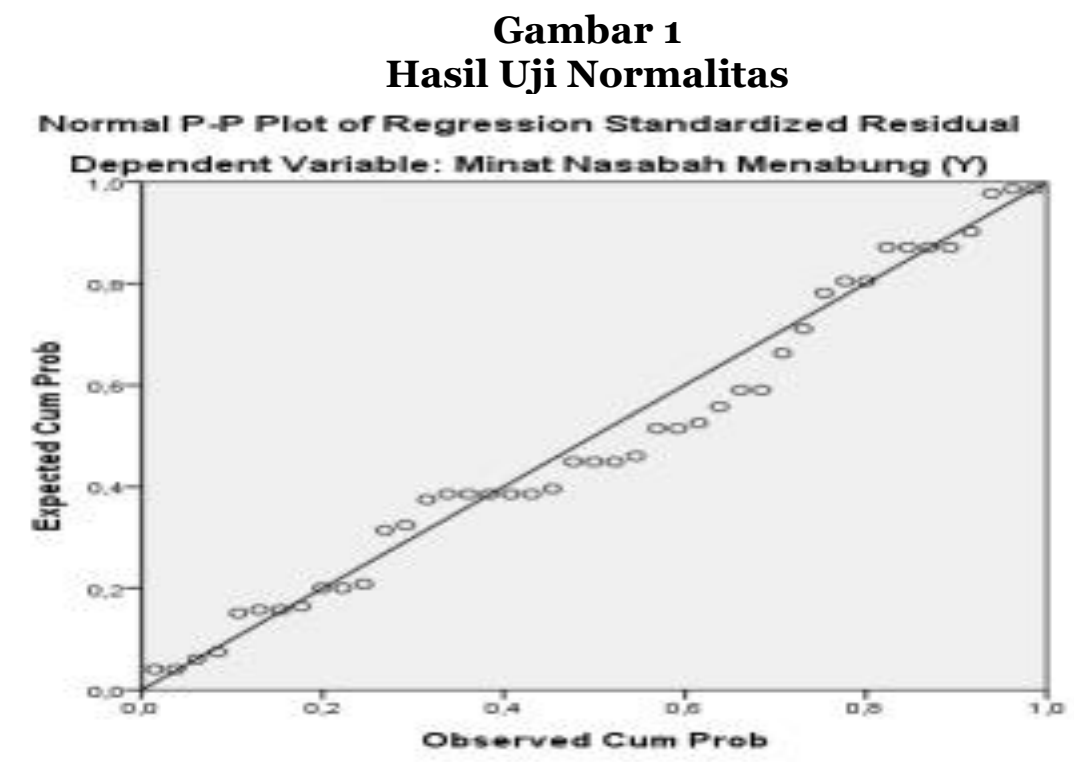

Berdasarkan gambar grafik normal proba-bility plot dapat diketahui bahwa sebaran titik-titik di sekitar garis diagonal yang berarti data tersebut berdistribusi normal sehingga model regresi dapat dipakai untuk memprediksi minat menabung di Bank Aceh Syariah KCP Sampoiniet.

Persamaan Regresi SederhanaAnalisis regresi sederhana digunakan untuk mengetahui dan memprediksi nilai suatu variabel dependen (Y) berdasarkan nilai suatu variabel independen (X). Dalam penelitian ini peneliti menggunakan variabel persepsi nasabah tentang atribut produk dari Bank Aceh Syariah KCP Sampoiniet sebagai variabel independen (X) dan variabel minat menabung di Bank Aceh Syariah(BAS) KCP Sampoiniet adalah variabel dependen (Y). Adapun persamaan regresi liniearsederhana dapat dinotasikan dalam rumus: $\mathbf{Y}=\boldsymbol{\alpha}+\boldsymbol{\beta} \mathbf{X}$

Hasil analisis data dari perhitungan program SPSS sebagai berikut:

Tabel 5

Coefficients $^{\mathbf{a}}$

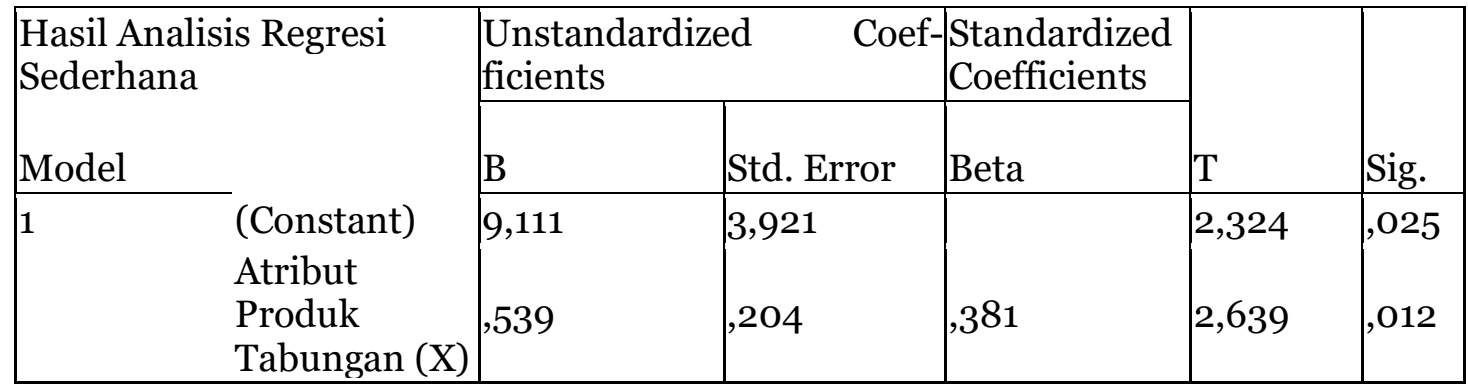

a. Dependen Variable: Minat Nasabah Menabung (Y)

Sumber: output SPSS 


\section{Atribut Produk Tabungan Bank Syariah Dan Pengaruhnya \\ Pada Minat Nasabah Menabung}

Ismaulina dan Agus Ana Tasya

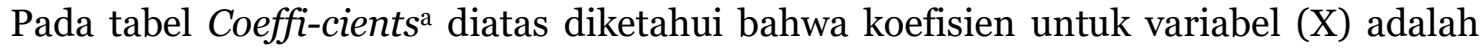
o.539 dan konstanta sebesar 9.111 sehingga persamaan regresi yang di peroleh adalah:

$\mathbf{Y}=\mathbf{9 . 1 1 1}+\mathbf{0 . 5 3 9 X}$

Di mana: $\quad \mathrm{X}=$ Variabel bebas (atribut produk)

$\mathrm{Y}=$ Variabel ter ikat (minat menabung)

Nilai konstan (Y) sebesar 9.111 artinya jika variabel independen Atribut Produk tabungan konstan pada nol, maka variabel dependen $(\mathrm{Y})$ konstan pada taraf 9.111. Koefisien regresi $X$ (atribut produk) $=0.539$ ini mengindikasikan bahwa setiap ada satu peningkatan atribut produk tabungan (X) maka minat menabung (Y) juga akan meningkat sebesar 53.9\% dengan anggapan konstan sebesar 9.111.

Uji Hipotesis Menggunakan Uji t atau Uji Parsial. Uji sta-tistik t bertujuan untuk melihat pengaruh variabel atribut produk tabungan ter- hadap minat nasabah menabung. Untuk menguji pengaruh parsial tersebut dapat di lihat berdasarkan nilai probabilitas dengan kriteria pengujian sebagai berikut:

a. Jika tingkat signifikansi lebih dari 5\% maka dapat di simpulkan bahwa Ho di terima dan Ha di tolak

b. Jika nilai signifikansinya lebih kecil dari lima \% maka dapat di simpulkan bahwa Hnul di tolak dan menerima Ha.

Untuk mengetahui hasil uji t dari koefisien variabel atribut produk tabungan terhadap minat menabung dapat di lihat pada tabel di bawah ini.

Tabel 6

Hasil Uji Parsial (Uji t)

\begin{tabular}{|c|c|c|c|c|c|c|}
\hline \multirow[b]{2}{*}{ Model } & & \multicolumn{2}{|c|}{$\begin{array}{l}\text { Unstandardized } \\
\text { Coefficients }\end{array}$} & \multirow{2}{*}{\begin{tabular}{|l} 
Standardized \\
Coefficients \\
Beta \\
\end{tabular}} & \multirow[b]{2}{*}{$\mathrm{t}$} & \multirow[b]{2}{*}{ Sig. } \\
\hline & & $\mathrm{B}$ & Std. Error & & & \\
\hline 1 & $\begin{array}{l}\text { (Constanta) } \\
\text { Atribut } \\
\text { Produk } \\
\text { Tabungan } \\
\text { (X) }\end{array}$ & $\begin{array}{l}9,111 \\
, 539\end{array}$ & 3,921 &, 381 & $\begin{array}{l}2,324 \\
2,639\end{array}$ & ,025 \\
\hline
\end{tabular}

a. Dependent Variable: Minat Nasabah Menabung (Y)

Dalam uji parsial dengan $\alpha=0.05$ dan $n=43$ diperoleh nilai $t_{\text {tabel }}$ sebesar 1.68288. Berdasarkan tabel di atas di simpulkan bahwa variabel in-dependen atribut produk tabungan berpengaruh positif dan signifikan terhadap minat nasabah pada Bank Aceh Syariah KCP

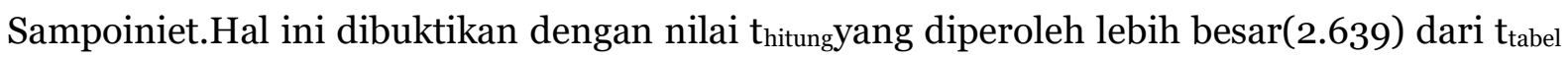
(1.68288) dan nilai signifikan 0.012 lebih kecil dari $\alpha=0.05$. Artinya hipotesis null di tolak dan memerima Ha. 
Uji Koefisien Determinasi $\left(\boldsymbol{R}^{2}\right)$. Uji Rsquare bertu-juan untuk mengetahui seberapa besar kemampuan variabel independen(bebas) menjelaskan variabel terikat. Nilai koefisiennya berkisar antara nol sampai satu. Nilai $\mathrm{R}^{2}$ yang kecil ber-arti kemampuan variabel b e $\mathrm{b}$ as dalam menjelaskan variabel dependen sangat terbatas, sebaliknya nilai yang mendekati satu bermakna variabel independen memberikan hampir semua informasi yang di butuhkan untuk memprediksi variabel ter ikat. Nilai koeffisien determinasinya dapat di lih at pada tabel 4.8 berikut:

\section{Tabel 7}

Hasil Koefisien Determinasi $\left(\mathbf{R}^{2}\right)$

\begin{tabular}{|l|l|l|l|l|}
\hline Model & $\mathrm{R}$ & R Squa-re & $\begin{array}{l}\text { Adjusted } \\
\text { Square }\end{array}$ & $\begin{array}{l}\text { Rtd. Error of } \\
\text { the Estimate }\end{array}$ \\
\hline $\mathbf{1}$ &, $381^{\mathrm{a}}$ &, $\mathbf{1 4 5}$ &, 124 & 2,808 \\
\hline
\end{tabular}

Dari pengolahan data ditabel 4.8 menunjukkan perolehan nilai koefisien korelasi (R) sebesar 38.1\%.Angka tersebut mengindikasikan bahwa hubungan antara variabel atribut tabungan terhadap minat nasabah menabung dalam kategori kurang kuat karena lebih kecil dari 50\%. Nilai $\mathrm{R}^{2}$ pada tabel diatas sebesar 0.145 atau $14,5 \%$. Sedangkan s i s anya $85.5 \%$ di terang-kan oleh variabel lain yang tidak di masukkan dalam model persamaan regresi pada penelitian ini.

Atribut produk tabungan Bank Aceh Syariah KCP Sampoiniet mempengaruhi minat nasabah dalam menabung.PT. Bank Aceh Syariah KCP Sampoiniet menyadari pentingnya atribut produk sebagai pertimbangan nasabah untuk menentukan minat menabung. Bank Aceh Syariah KCP Sampoiniet selalu menetapkan kebijakan atribut produk tabungan yang tentunya di sesuaikan dengan kebutuhan masyarakat yang semakin berkembang. Peningkatan dan pengembangan atribut produk tabungan menunjukkan bahwa Bank Aceh Syariah KCP Sampoiniet berusaha untuk meningkatkan jumlah nasabahnya. Atribut produk tabungan yang di miliki oleh Bank Aceh Syariah KCP Sampoiniet di antaranya adalah:

Merek.Bank Aceh Syariah KCP Sampoiniet merupakan perusahaan perbankan pembangunan daerah istimewa Aceh yang lebih di kenal dengan Bank BPD Aceh Syariah dan di sertai dengan logo perusahaan. Bank Aceh Syariah KCP Sampoiniet telah menjadi perusahaan publik yang di miliki oleh masyarakat, penetapan merek yang di lakukan oleh Bank Aceh Syariah KCP Sampoiniet pada salah satu produk Bank Aceh misal tabungan firdaus, pemberian nama tersebut memiliki makna yang jelas serta mudah di ingat di mata masyarakat, sebagai tabungan untuk mempersiapkan kehidupan atau memenuhi kebutuhan nasabah di kemudian hari. 


\section{Atribut Produk Tabungan Bank Syariah Dan Pengaruhnya \\ Pada Minat Nasabah Menabung}

Ismaulina dan Agus Ana Tasya

Desain Produk/Kemasan. Desain dan warna buku tabungan Bank Aceh syariah. Tabungan pada Bank Aceh Syariah KCP Sampoiniet memiliki buku tabungan dengan cover berwarna hijau tua di sertai dengan logo PT. Bank Aceh Syariah. Tulisan yang ada pada buku tabungan Bank Aceh Syariah terlihat dengan jelas serta mudah di baca dan di pahami oleh nasabah. Desain dan warna buku tabungan Bank Aceh Syariah di dominasi oleh warna kuning kehijauan, hijau muda dan hijau sedang sebagai warna dari logo perusahaan Bank Aceh Syariah, supaya nasabah dapat mengenal desain dan warna buku tabungan Bank Aceh Syariah walaupun hanya sekilas.

Desain kartu ATM Bank Aceh SyariahDesain kartu ATM Bank Aceh Syariah (BAS) yang di tetapkan oleh Bank Aceh Syariah tidak sama dengan warna di buku tabungan, yaitu di dominasi dengan warna biru muda dan di lengkapi dengan logo Bank Aceh Syariah yang ber-warna kuning kehijauan, hijau muda dan hijau sedang. Hal tersebut di maksudkan untuk memperkuat perusahaan di mata masyarakat, bahwa kartu ATM tersebut merupakan salah satu produk dari Bank Aceh Syariah.

Pemberian Label. Pada buku tabungan Bank Aceh Syariah, terdapat informasi dan keterangan yang cukup lengkap mengenai kode transaksi, identitas pemilik rekening tabungan, saldo nasabah, biaya administrasi, tanggal transaksi, aktifitas transaksi dan lainnya.Hal tersebut di maksudkan agar nasabah mendapatkan informasi yang jelas mengenai aktifitas transaksi perbankan yang telah di lakukan oleh nasabah.Ketersediaan ATM. Nasabah dapat menggunakan kartu ATM dengan fasilitas ATM Bank Aceh Syariah yaitu dapat melakukan transaksi di 201 gerai ATM Bank Aceh. Fasilitas ATM tersebut memberikan jasa layanan selama 24 jam, serta di sediakan pula fasilitas lain bagi pemegang kartu ATM seperti informasi saldo, ubah PIN, ta riktunai, trans-fer antar rekening, serta menda-patkan fasilitas transfer antar rekening secara real time online. Ketersediaan ATM yang tersebar pada beberapa wilayah tersebut di maksudkan untuk mempermudah nasabah yang akan melakukan aktifitas perbankan tanpa keterbatasan waktu dan tempat.

Harga.PT. Bank Aceh Syariah menetapkan setoran awal yang relatif ringan pada para calon nasabah tabungan Bank Aceh Syariah yaitu Rp 20.00o, dengan saldo minimum Rp 50.00o, biaya administrasi tabungan (tergantung produk tabungan di Bank Aceh Syariah), dan nasabah bisa menentukan sendiri target mana yang ingin di capai dengan tabungan Bank Aceh Syariah.

Dari hasil analisa data di atas, di ketahui bahwa atribut produk yang diterapkan pada Bank Aceh Syariah KCP Sampoiniet sudah sesuai dengan syariat Islam meskipun belum sampai pada taraf yang menyeluruh seperti penggunaan simbol-simbol atau atribut ke Islaman.Namun demikian, secara keseluruhan hasil temuan peneliti di lapangan, Atribut 
produk yang dilakukan oleh Bank Aceh Syariah KCP Sampoiniet sudah dilaksanakan dengan baik.Konsep yang ditemukan dalam Bank Aceh Syariah KCP Sampoiniet sudah mencakup 5 aspek penting sebagaimana teori yang telah peneliti sajikan di bab-bab sebelumnya.

Adapun 5 aspek yang tercermin dalam atribut produk tabungan di antaranya adalah: (1) Tidak mengandung unsur riba. (2) Hasil investasi dibagi menurut sistem bagi hasil. (3) Menghin-dari unsur gam-bling/judi (maisir). (4) Melakukan investasi yang halal. (5) Melakukan aktivitas sesuai dengan syari'ah. Dari tabel 4.7 menunjukkan nilai $t_{\text {hitung }}$ sebesar 2.639. Sementara nilai $t_{\text {tabel }}$ pada $a=0.05$ diperoleh nilai sebesar 1.68288 artinya $t_{\text {hitung }}>t_{\text {tabel }}$. Berdasarkan persamaan regresi juga terlihat bahwa nilai koefisien atribut produk tabungan benilai yaitu 0.539 dengan tingkat signifikannya sebesar $0.012<0.05$ maka keputusannya Ha diterima dan dapat diartikan secara parsial bahwa variabel atribut produk tabungan berpengaruh terhadap minat nasabah menabung. Hal ini sejalan dengan penelitian Ismaulina \&Maisyarah(2020) tentang Pengaruh Lebeli-sasi Halal, C it ra Merek, dan harga terhadap Keputusan Pembelian Produk Makanan Mie Instant Indomie. Dimana atribut produk dari mie instant indomie yakni lebelisasi halal dan citra merek berpengaruh terhadaap keputusan pembelian barang.Sama halnya dengan penelitian Rutmaira Sitinjak (2015) bahwa atribut produk islami mempengaruhi kepuasan nasabah bank BNI Pekanbaru.

Dari penjelasan diatas dapat diketahui bahwa variabel atribut produk tabungan berpengaruh terhadap minat nasabah menabung, hal ini dapat dibuktikan dengan banyaknya iklan promosi yang ditawarkan oleh pihak Bank Aceh Syariah KCP Sampoiniet sangat menarik perhatian nasabah.Dengan hal tersebut dalam penelitian ini dapat diketahui alasan para nasabah menjadi nasabah di Bank Aceh Syariah KCP Sampoiniet bukan didasari oleh faktor syariah ataupun pelayanan.

Atribut produk tabungan Bank Aceh Syariah KCP Sampoiniet berpengaruh secara signifikan terhadapminat nasabah dalam menabung. Dari hasil koefisien regresi diketahui bahwa besarnya parameter standar koefisien regresi $\beta$ untuk variabel terikat yaitu variabel atribut produk tabungan terhadap variabel bebas yaitu minat menabung di Bank Aceh Syariah KCP Sampoiniet adalah sebesar 0.539.Dari persamaan regresi terlihat bahwa parameter koefisien regresi untuk variabel atribut produk negatif terhadap minat menabung di Bank Aceh Syariah KCP Sampoiniet. Dengan demikian setiap terjadi peningkatan variabel atribut produk, maka minat menabung di Bank Aceh Syariah KCP Sampoiniet juga akan mengalami perubahan. Dengan demikian pengajuan hipotesis 1 diterima.Dan besarnya pengaruh atribut produk terhadap minat menabung di Bank Aceh Syariah KCP Sampoiniet adalah 14.5\%. Adapun persa-maan regresi yang diperoleh adalah sebagai berikut: $\mathrm{Y}=9.111+0.539 \mathrm{X}$ 


\section{Atribut Produk Tabungan Bank Syariah Dan Pengaruhnya \\ Pada Minat Nasabah Menabung}

Ismaulina dan Agus Ana Tasya

Perhitungan validitas kuesioner (untuk nasabah) menunjukkan bahwa validitas tiap butir pernya-taan berada pada kate-gori cukup menurut klasifikasi Prasetyo.Analisis T-test independent pada kuesioner yang peneliti bagikan pada responden (Bank Aceh Syariah KCP Sampoiniet) menunjukkan bahwa ada pengaruh yang signifikan antara variabel bebas dengan variabel terikatnya.Angka statistik uji $t_{\text {hitung }}$ menunjukkan angka yang jauh lebih besar jika dibandingkan $t_{\text {tabel }}(2.639>1.68288)$ memberi bukti empiris bahwa hipotesa yang di ajukan oleh peneliti tidak dapat di tolak.

Pada kuesioner di item pertanyaan yang ke empat dan lima (item pertanyaan pada variabel menghindari unsur ghambling (judi) dan melakukan investasi yang halal) dan item pertanyaan ke empat (item pertanyaan pada variabel minat nasabah menabung untuk indikator informasi sebelum menjadi nasabah) diperoleh bahwa ada perbedaan bermakna rata-rata skor jika di bandingkan dengan beberapa indikator lainnya, kedua indikator tersebut yang paling mendapatkan total skor terendah. Ini terjadi kemungkinan karena tingkat kepercayaan nasabah terhadap Bank Aceh Syariah KCP Sampoiniet yang masih belum seutuhnya dan tingkat promosi yang masih tergolong rendah yang memiliki kecenderungan tidak begitu familiar di telinga masyarakat umum tentang informasi yang diberikan oleh Bank Aceh Syariah KCP Sampoiniet tersebut.

Perhitungan reabilitas kedua kuesioner (variabel atribut produk dan variabel minat menabung di Bank Aceh Syariah KCP Sampoiniet) menunjukkan bahwa reabilitas tiap variabel dalam kuesioner ini seluruhnya berada dalam kategori cukup menurut klasifikasi Sutrisno yang berada pada kisaran 0.60 sampai 0.80 (0.706 dan 0.703).Variasi Atribut Produk tabungan Bank Aceh Syariah KCP Sampoiniet cukup baik.Hasil regresi juga menunjukkan bahwa skor atribut produk tabungan baik di gunakan untuk meramalkan minat nasabah menabung di Bank Aceh Syariah KCP Sampoiniet. Nilai R square menunjukkan angka 0.145 mengasumsikan bahwa kemampuan variabel independen dalam menjelaskan dan meramalkan variabel besaran minat nasabah menabung di Bank Aceh Syariah KCP Sampoiniet adalah sebesar 14.5\%. Artinya Atribut Produk tabungan yang terdiri dari 5 indikator tersebut yaitu: (1) Tidak mengandung unsur riba. (2) Hasil investasi di bagi menurut sistem bagi hasil. (3) Menghindari unsur ketidakpastian (gambling)/judi (maisir). (4) Melakukan investasi yang halal. (5) Melakukan aktivitas sesuai dengan syariah tertarik menginvestasikan atau menabungkan dana mereka terhadap Bank Aceh Syariah KCP Sampoiniet.

\section{Kesimpulan}

Berdasarkan hasil penelitian dan pembahasan yang mengacu pada bab-bab sebelumnya yang meng-uraikan tentang bagaimana pengaruh variabel atribut produk tabungan ter- 
hadap minat nasabah menabu-ng di Bank Aceh Syariah KCP Sampoiniet maka dapat ditarik kesimpulan sebagai berikut:

Konsep yang ditemukan pada Bank Aceh Syariah berkaitan dengan atribut produk tabungan terhadap nasabah/customer mengindikasikan bahwa se-tidaknya ada 5 hal penting yang menjadi perhatian tersendiri bagi nasabah. Dalam angket tertutup yang disajikan dengan 5 indikator utama tersebut (tidak mengandung unsur riba, hasil investasi dibagi menurut sistem bagi hasil, menghindari unsur g a $\mathrm{m}$ b l i ng atau judi, melakukan investasi yang halal, melakukan aktivitas sesuai dengan sya-riah) mayoritas responden memberikan jawaban mengarah pada kualitas atribut produk yang dilakukan di Bank Aceh Syariah KCP Sampoiniet telah dijalankan dengan baik.

Hasil pengujian hipotesa uji t untuk variabel atribut produk tabungan di peroleh $t_{\text {hitung }}$ sebesar 2.639 dengan tingkat sig. 0.012 (lebih kecil dari taraf sig-nifikan 0.05) sehingga dapat dikatakan bahwa variabel atribut produk tabungan secara parsial mempunyai pengaruh signifi-kan terhadap variabel minat nasabah menabung di Bank Aceh Syariah KCP Sampoiniet.

\section{Daftar Pustaka}

Agung Purwo Atmojo,Analisis Pengaruh Kualitas Layanan, Nilai Nasabah, dan Atribut Produk Islam Terhadap Kepuasan Nasabah. (Studi Kasus Pada BNI Syariah Cabang Semarang)".(Skripsi 2010) UNDIP Semarang, Indonesia

Agus Bastiar, "Pengaruh atribut produk Islam, komitmen agama, kualitas jasa, dan kepercayaan terhadap kepuasan nasabah PT BPRS Puduarta Insani Tembung" (Studi Kasus Pada Nasabah PT BPRS Puduarta Insani Tembung)". (Skripsi 2012) Universitas Negeri Yogyakarta, Indonesia

Algifari,Statistika Induktif, Yogyakarta: YKPN, 2003.

Daromi, dkk, Kebijakan Bauran Pemasaran.Yogyakarta: BPFE, 1992.

Erna Ferrinadewi, Atribut Produk yang Dipertimbangkan dalam Pembelian Kosmetik dan Pengaruhnya pada Kepuasan Konsumen di Surabaya. (Jurnal Manajemen dan Kewirausahaan Universitas Petra, Vol. 7. No. 2.2005) Fakultas Ekonomi-Universitas Kristen Petra, Indonesia

Fandy Tjiptono, Strategi Pemasaran, Yogyakarta: Andi, 2008.

Heri Sudarsono dan Priyonggo Suseno, Istilah-istilah Bank dan Lembaga Keuangan Syariah. Yogyakarta: UII Press, 2004.

Imamul Arifin, Membuka Cakrawala Ekonomi,Jakarta: Setia Purna Inves, 2007.

Ismail,Perbankan Syariah, Jakarta: Kencana, 2011. 


\section{Atribut Produk Tabungan Bank Syariah Dan Pengaruhnya \\ Pada Minat Nasabah Menabung}

Ismaulina dan Agus Ana Tasya

Ismaulina,Pengaruh Lebelisasi-Halal, Citra Merek, dan Harga terhadap Keputusan Pembelian Mie Instant Indomie. (Manajerial: Jurnal Manajemen dan Sistim Informasi, 19(2), 185-197, 2020) Universitas Pendidikan Indonesia

Koentjaraningrat, Metode-metode Penelitian Masyarakat, Cet. XIII, Jakarta: PT. Gramedia, 1994.

Luthfi Hamidi, Jejak-Jejak Ekonomi Syariah, Jakarta: Senayan Abadi Publishing, 2003.

Malayu Hasibuan, Dasar-dasar Perbankan, Jakarta: Bumi Aksara, 2008.

Muhammad Syafii Antonio, Bank Syariah dari Teori ke Praktik, Jakarta: Gema Insani, 2001.

Muhammad,Sistem dan Prosedur Operasional Bank Syariah Edisi Revisi. Yogyakarta: UII Press, 2008.

Philip Kotler,Manajemen Pemasaran, Edisi Sebelas,Jakarta: Indeks, 2003.

Priyanto Buwi, Mandiri Belajar SPSS untuk Analisa Data dan Uji Statistic, Edisi 1. Jakarta: Salemba Empat, 2008.

PriyatnoDwi, Mandiri Belajar SPSS, untuk Analisis Data dan Uji Statistik. Yogyakarta: Media Kom, 2008

Rahman El Junusi, Pengaruh Atribut Produk Islam, Komitmen Agama, Kualitas Jasa dan Kepercayaan Terhadap Kepuasan dan Loyalitas Nasabah Bank Syariah (Pada Bank Muamalat Kota Semarang)". (Skripsi Prodi Ekonomi Islam Fakultas Syariah IAIN Walisongo 2009). IAIN Walisongo, Indonesia.

Rahman El-Yunusi, Jurnal. Pengaruh Atribut Produk Islam, Komitmen Agama, Kualitas Jasa dan Kepercayaan terhadap Kepuasan dan Loyalitas Nasabah Bank Syariah (pada Bank Muamalat Kota Semarang), (Jurnal. Annual Converennce on Islamic Studies (ACIS) ke 9 tahun, 2009)Surakarta, Indonesia

Rutmaira Sitinjak, Analisis Pengaruh Atribut Produk Islami Dan Kualitas Pelayanan Terhadap Kepuasan Nasabahdan Loyalitas Nasabah Pada PT Bank Negara Indonesia Syariah (BNI SYARIAH) Pekanbaru (Jurnal Online Mahasiswa, Jom FEKON Vol. 2 No. 2 Oktober 2015) Universitas Riau, Indonesia

Sugiono, Metode Penelitian Kuantitatif, Kualitatif,Bandung: Alfabeta, 2011.

Suharsimi Arikunto, Prosedur Penelitian;Suatu Pendekatan Praktik, Edisi Revisi ke 6, Jakarta: Renika Cipta, 2012.

Sumber Data (arsip) PT. Bank Aceh Syariah Capem Samponiet 2017.

Sunarto Zulkifli, Panduan Praktis Transaksi Perbankan Syariah, Jakarta: Zikrul Hakim, 2003.

Ujang Suwarman, Perilaku Konsumen: Teori dan Penerapannya dalam pemasaran, Bogor: Ghalia Indonesia, 2004. 